\title{
SIMULASI VIBRASI BERBASIS METODE ELEMEN HINGGA MENGGUNAKAN SOFTWARE ANSYS UNTUK MENGIDENTIFIKASI KONDISI PADA SUDU KOMPRESOR TURBIN GAS SIEMENS V 94.2 SEBAGAI PEMBANGKIT LISTRIK
}

\author{
Ikhwansyah Isranuri, Muhammad Asroh Hasibuan \\ Departemen Teknik Mesin Fakultas Teknik Universitas Sumatera Utara \\ Muhammad.asroh29@gmail.com
}

\begin{abstract}
ABSTRAK
Vibrasi memiliki banyak pengaruh dalam proses permesinan, analisis getaran digunakan sebagai alat diagnostic untuk memperkirakan kondisi dan kerasukan suatu komponen. Penelitian ini bertujuan untuk Memproyeksikan deformasi total, regangan elastis normal, tegangan normal yang terjadi pada sudu kompresor dan untuk Menganalisa vibrasi yang terjadi pada sudu kompresor. Dalam penelitian ini digunakan kompresor turbin gas siemens $v 94.2$ dengan jumlah sudu 16 tingkat. Dalam proses melakukan simulasi menggunakan software ANSYS Workbench 18.1 dan proses design menggunakan software Solidworks 2015. Dalam proses simulasi digunakan dua kecepatan putar yaitu $3000 \mathrm{rpm}$ dan $5000 \mathrm{rpm}$ dengan pemberian beban dinamis dari tiga sumbu dan di pengaruhi oleh gaya gravitasi. Pemilihan material dari kompresor ini adalah baja, proses design digunakan dalam bentuk solid Dari hasil perbandingan diperoleh total deformation dan normal mengalami kenaikan paling tinggi pada arah vertikal. Hal ini dipengaruhi oleh gaya gravitasi yang terjadi pada kompresor, karena pada arah vertikal pembebanan dilakukan berlawanan dengan gaya gravitasi. Didapatkan juga ketika kecepataan putar dirubah dari 3000 rpm menjadi 5000 rpm, total deformation, normal elastic strain, dan normal stress hampir naik tiga kali lipat.stress mengalami penurunan pada arah vertikal sedangkan normal elastic strain dan kompresor aman dari frekuensi kritis.
\end{abstract}

Kata kunci: Simulasi vibrasi, Turbin gas siemens v 94.2, Software ANSYS, Kompresor, Frekuensi.

\section{PENDAHULUAN}

Seiring perkembangan zaman, jumlah penduduk semakin bertambah yang berarti semakin bertambah pula kebutuhan akan energi listrik. Salah satu solusi untuk permasalahan tersebut yaitu dengan membangun PLN (Perusahaan Listrik Negara) sebagai penyedia energi listrik skala besar. Proses pembangkitan energi listrik dapat digunakan dengan berbagai cara. Salah satunya pembangkit listrik bertenaga uap.

Turbin gas merupakan salah satu komponen pada pembangkit bertenaga uap, didalam turbin gas terbagi lagi dalam beberapa komponen yaitu turbin, kompresor, combustion chamber dan generator. Pada tugas sarjana ini difokuskan untuk melakukan analisa pada kompresor. Kondisi dari kompresor sangat berpengaruh terhadap kinerja dari turbin gas karena kompresor berfungsi untuk menaikkan tekanan udara sehingga dapat memutar turbin. Oleh karena itu pemantauan kondisi dari kompresor perlu dilakukan untuk mendeteksi keadaan dan kerusakan pada kompresor. Deteksi dini pada kompresor sangat penting untuk mencegah kerusakan yang terjadi dan untuk menjaga kondisi kompresor pada turbin gas. 
Analisis getaran (vibrasi) digunakan sebagai alat diagnostik untuk memperkirakan kondisi dan kerusakan pada kompresor. Karena kompresor memiliki prinsip kerja rotasi, kondisi dan kerusakan dapat di deteksi dari frekuensi getaran yang terjadi pada kompresor. Frekuensi tersebut didapatkan dengan melakukan pengukuran pada kompresor yang dilakukan setiap bulannya.

Pada tugas sarjana ini proses analisis dilakukan dengan bantuan software ANSYS, yaitu dengan melakukan simulasi getaran (vibrasi) dengan frekuensi yang didapatkan dari pengukuran. Dari simulasi getaran (vibrasi) didapatkan kondisi dan titik terjadinya getaran yang melebihi batas izin getar sehingga mempermudah perawatan dan pemantauan kondisi dari kompresor. Kompresor yang dipergunakan pada tugas ini adalah kompresor 16 tingkat pada turbin gas siemens v 94.2 yang terdapat pada pembangkit listrik tenaga uap (PLTU) belawan, sumatera utara.

\section{TINJAUAN PUSTAKA}

Kompresor adalah mesin untuk memampatkan udara atau gas. Kompresor udara biasanya mengisap udara dari atmosfir. Namun adapula yang mengisap udara atau gas yang bertekanan lebih tinggi dari tekanan atmosfir. Dalam hal ini kompresor bekerja sebagai penguat (booster). Sebaliknya adapula kompresor yang mengisap gas yang bertekanan lebih rendah dari tekanan atmosfir. Dalam hal ini kompresor disebut pompa vakum. Secara umum kompresor dibedakan menjadi dua jenis yaitu kompresor perpindahan positif dan kompresor dinamis. Kompresor merupakan suatu alat mekanik yang berfungsi untuk meningkatkan tekanan fluida mampu mampat, yaitu gas atau udara. Adapun tujuan dari meningkatkan tekanan adalah untuk menghasilkan kebutuhan tekanan dalam suatu sistem proses yang lebih besar (dapat berupa sistem fisika maupun kimia seperti pengaplikasian kompresor pada turbin di pembangkit listrik)

Getaran adalah suatu peristiwa gerak bolak balik secara teratur suatu benda melalui satu titik seimbang. Karena terjadi dengan teratur, getaran sering juga disebut dengan gerak periodik. Kuat atau lemahnya pergerakan benda tersebut dipengaruhi oleh jumlah energi yang diberikan. Semakin besar energi yang diberikan maka semakin kuat pula getaran yang terjadi. Satu getaran sama dengan satu kali gerakan bolak balik penuh dari benda tersebut

Mechanical Vibration atau Getaran Mekanis merupakan suatu istilah yang kemunculannya telah melalui proses panjang. Untuk memahami getaran mekanis, orang terlebih dahulu harus memahami makna mekanika sebagai cabang ilmu pengetahuan, karena getaran merupakan salah satu fenomena dari mekanika. Tinjauan sejarah perkembangan mekanika dan getaran tidak lepas dari dua aspek, yaitu hukum alam dan rekayasa. Yang menarik dalam sejarah 
hukum alam dan rekayasa, apabila kita fokus pada runtuhnya peradaban Islam abad ke-3, hampir semua pakar mekanika terlebih dahulu membahas interpretasi hukum alam, aksioma, uraian, bahkan rumus matematika. Dan hal ini dilakukan terlebih dahulu sebelum membahas rekayasa, aplikasi, serta hubungan dari masing-masing hukum alam tersebut. Bahkan, tinjauan terhadap hukum alam pada abad ke-3 dilakukan sampai pada esensi yang paling dalam, yaitu filosofi.

Terdapat tiga parameter utama dalam pengukuran vibrasi terhadap sebuah mesin, yaitu : displacement, velocity dan acceleration yang harus diperhatikan sebelum menganalisa penyebab terjadinya vibrasi yang tidak normal.

FEM adalah singkatan dari Finite Element Method, dalam bahasa Indonesia disebut Metode Elemen Hingga. Konsep paling dasar FEM adalah, menyelesaikan suatu problem dengan cara membagi obyek analisa menjadi bagian-bagian kecil yang terhingga. Bagian-bagian kecil ini kemudian dianalisa dan hasilnya digabungkan kembali untuk mendapatkan penyelesaian untuk keseluruhan daerah. Kata "finite atau terhingga" digunakan untuk menekankan bahwa bagian-bagian kecil tersebut tidak tak terhingga, seperti yang lazim digunakan pada metode integral analitik. Pembuatan mesh atau yg lebih dikenal dengan istilah meshing, merupakan salah satu langkah dalam pre-processing sebuah simulasi. Baik untuk simulasi struktural yg menggunakan Finite Element Method (FEM), maupun simulasi CFD yang umumnya menggunakan Finite Volume Method (FVM). Mesh ini sendiri berguna untuk membagi geometry dari model menjadi banyak elemen yang nantinya digunakan oleh solver untuk membangun volume kontrol

Solidwork adalah software yang digunakan untuk membuat desain produk yang sederhana hingga yang kompleks seperti roda gigi, cashing handphone, mesin mobil dan sebagainya. Solidwork menyediakan feature based, parametric solid modeling. Feature based dan parametric ini yang akan sangat mempermudah dalam membuat model 3D. Karena hal ini membuat kita sebagai user bisa membuat model sesuai dengan intuisi kita. Solidwork simulation memungkinkan anda untuk melakukan uji produk sebelum mulai dibuat, membantu mencegah kesalahan lebih awal pada proses desain. Aplikasi ini sangat berguna untuk analis FEA, namun cukup mudah untuk designers produk. Solidwork simulation bahkan bisa membantu anda untuk mengoptimalkan kinerja dan biaya desain anda dengan maksimal. Tidak perlu menunggu sampai produk dibuat untuk melakukan tes, atau membuat berbagai macam prototipe.

ANSYS adalah program paket yang dapat memodelkan elemen hingga untuk menyelesaikan masalah yang berhubungan dengan mekanika, termasuk di dalamnya masalah 
statik, dinamik, analisis struktural (baik linier maupun nonlinier), masalah perpindahan panas, masalah fluida dan juga masalah yang berhubungan dengan akustik dan elektromagnetik.

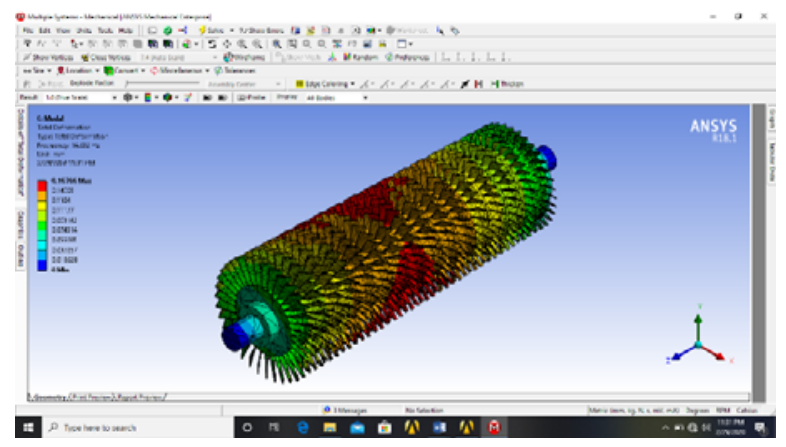

Gambar 2.1 Proses Simulasi dengan Software ANSYS

\section{METODE PENELITIAN}

Tempat penelitian dilakukan di laboratorium Pusat Riset Noise and Vibration Control, Departemen Teknik Mesin Universitas Sumatera Utara. Pada penelitian ini, alat yang digunakan untuk melakukan pemodelan dengan menggunakan software Solidwork dan untuk melakukan simulasi menggunakan software ANSYS adalah laptop.

Perancangan kompesor 16 tingkat ini didesain langsung dalam bentuk 3D dengan menggunakan software Solidwork. Solidwork yang digunakan pada pemodelan skripsi ini yaitu solidwork 2015. Sedangkan data dimensi kompresor 16 tingkat siemen v 94.2 didapatkan dari PLTU Belawan, Sumatera Utara.

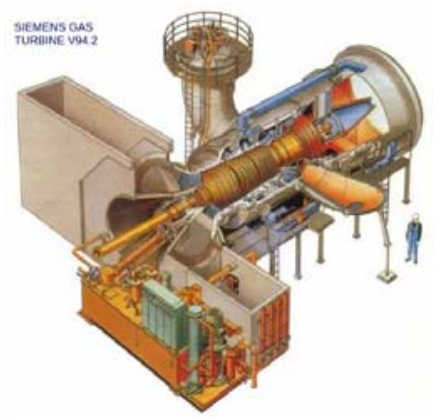

(a)

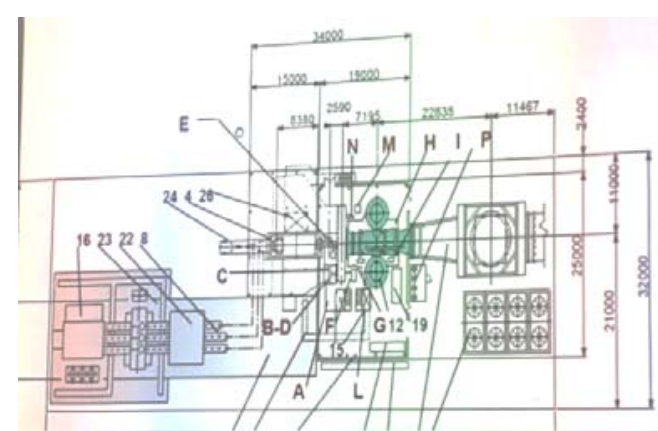

(b)

Gambar 3.1 (a) Turbin Gas Siemens v 94.2 (b) Gambar Kerja

Turbin Gas Siemens v 94.2

Proses simulasi digunakan menggunakan software ANSYS, adapun software ANSYS yang digunakan peneliti adalah software ANSYS 18.1. Proses simulasi yang digunakan yaitu 
simulasi statik struktural. Adapun proses simulasi dilakukan dengan Engineering data, berisi data dari material yang digunakan, karena material dari turbin gas siemens v 94.2 yaitu baja, selanjutnya Geometri, yang digunakan pada peneltitian ini adalah solid. Meshing bertujuan untuk membagi komponen komponen dalam bentuk sel sehingga memperjelas hasil komputasi, mempermudah proses komputasi, dan untuk membuat jaring-jaring atau ayakan pada kompresor. Adapun tipe meshing yang peneliti gunakan adalah Coarse (kasar), dengan bentuk tetrahedron dan memiliki panjang sisi paling kecil dengan ukuran $10 \mathrm{~mm}$.

Selanjutya support, bertujuan untuk mengekang atau tumpuan pada kompresor penelitian ini menggunakan displacement support. Salah satu parameter yang peniliti gunakan adalah memasukkan gaya gravitasi bumi. Parameter kecepatan putar (rotational velocity), kecepatan putar pada kompresor adalah $3000 \mathrm{rpm}$ dan $5000 \mathrm{rpm}$. Pembebanan yang diberikan adalah pembebanan dinamis dengan memberikan gaya (force) selama 3 detik.

Pada kecepatan putar 5000 rpm nilai frekuensi pada ketiga sumbu hasilnya sama, frekuensi yang dihasilkan adalah 32,816 Hz, 102,66 Hz, 102,95 Hz, 135,36 Hz. Pada kecepatan putar 3000 rpm nilai frekuensi pada ketiga sumbu hasilnya sama, frekuensi yang dihasilkan adalah 14,632 Hz, 14,885 Hz, 32,758 Hz, 88,602 Hz. Frekuensi kerja pada kecepatan $3000 \mathrm{rpm}$ adalah $50 \mathrm{~Hz}$, frekuensi kerja pada kecepatan $5000 \mathrm{rpm}$ adalah 83,3 Hz.

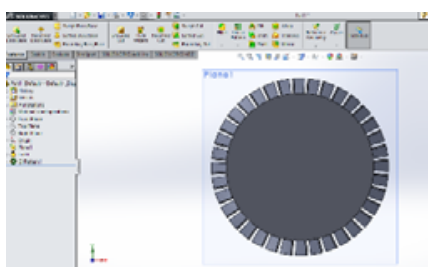

(a)

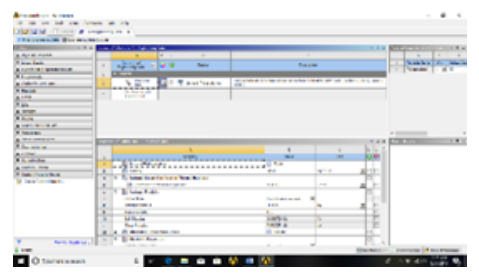

(b)

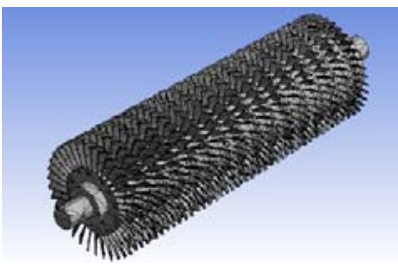

(c)

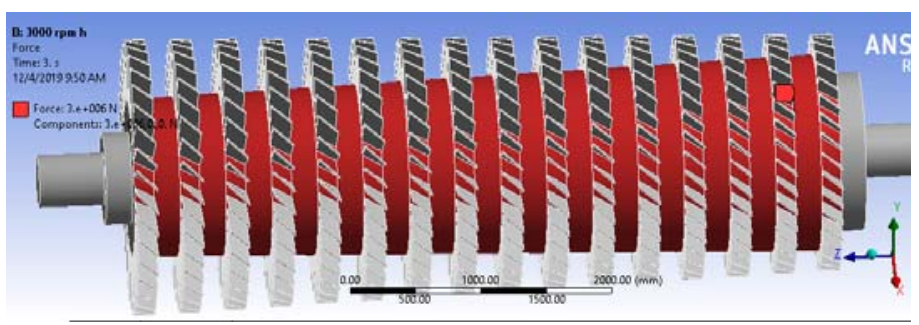

(d)

Gambar 3.2 (a) Proses Design Kompresor dengan Solidwork, (b) Engineering Data,

(b) Hasil Meshing Kompresor, (d) Pembebanan pada Kompresor.

Dari hasil penelitian ini dapat kita lihat pada kecepatan putar $3000 \mathrm{rpm}$ nilai frekuensi natural pada ketiga sumbu hasilnya sama, frekuensi yang dihasilkan adalah 14,632 Hz, 14,885 $\mathrm{Hz}, 32,758 \mathrm{~Hz}, 88,602 \mathrm{~Hz}$. Pada kecepatan putar $5000 \mathrm{rpm}$ nilai frekuensi natural pada ketiga sumbu hasilnya sama, frekuensi yang dihasilkan adalah $32,816 \mathrm{~Hz}, 102,66 \mathrm{~Hz}, 102,95 \mathrm{~Hz}$, 
135,36 Hz. Frekuensi kerja kompresor pada kecepatan $3000 \mathrm{rpm}$ adalah $50 \mathrm{~Hz}$ dan pada kecepatan $5000 \mathrm{rpm}$ adalah 83,3 Hz sehingga aman dari frekuensi kritis kompresor.

\section{HASIL PENELITIAN DAN PEMBAHASAN}

Pembuatan model 3D kompresor 16 tingkat mempunyai panjang $6800 \mathrm{~mm}$ dan diameter tie road $400 \mathrm{~mm}$. Dengan ukuran terbesar sudu berdiameter $2100 \mathrm{~mm}$ dan sudu terkecil berdiameter $1800 \mathrm{~mm}$. Hollow shaft terbesar berdiameter $1500 \mathrm{~mm}$ dan hollow shaft terkecil berdiameter $1200 \mathrm{~mm}$. Desain kompresor 16 tingkat ini memiliki volume $8.549 .800 .000 \mathrm{~mm}^{3}$ dan memiliki massa $67.116 \mathrm{~kg}$.

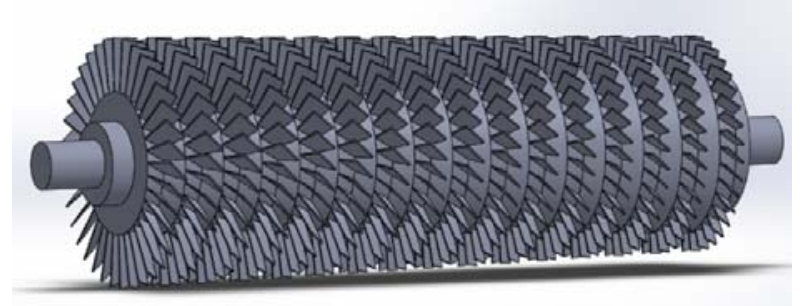

Gambar 4.1 Design 3D Kompresor

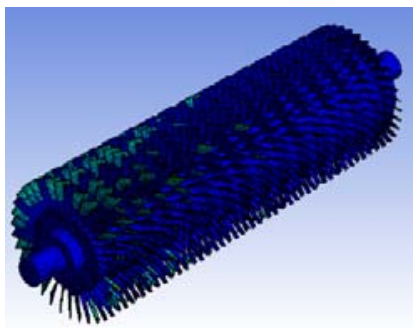

(a)

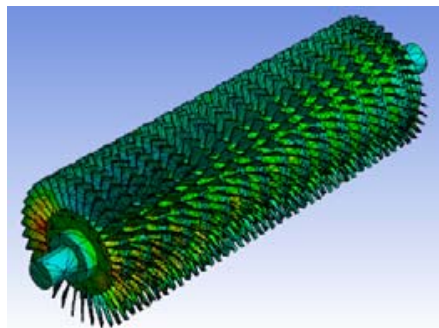

(b)

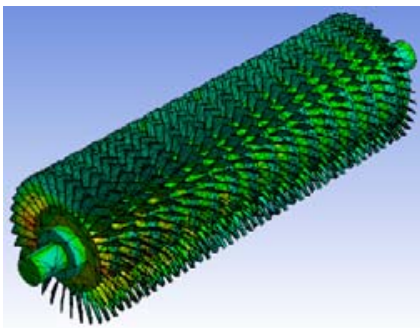

(c)

Gambar 4.2 (a) Total Deformasi (b) Regangan Normal (c) Tegangan Normal pada Arah Horizontal dengan Kecepatan 3000 rpm

Tabel 4.1 Hasil Simulasi pada Sudu Kompresor 16 Tingkat

\begin{tabular}{|l|c|c|c|}
\hline Kecepatan putar 3000 rpm & Horizontal & Vertikal & Aksial \\
\hline Total Deformation (mm) & 12,435 & 12,308 & 12,509 \\
\hline $\begin{array}{l}\text { Normal Elastic Strain } \\
(\mathrm{mm} / \mathrm{mm})\end{array}$ & 0,0014862 & 0,0015079 & 0,0014807 \\
\hline Normal Stress (MPa) & 323,01 & 322,07 & 323,27 \\
\hline Kecepatan putar 5000 rpm & \multicolumn{3}{|l}{} \\
\hline Total Deformation (mm) & 34,338 & 34,211 & 34,412 \\
\hline
\end{tabular}




\begin{tabular}{|l|c|c|c|}
\hline $\begin{array}{l}\text { Normal Elastic Strain } \\
(\mathrm{mm} / \mathrm{mm})\end{array}$ & 0,0041577 & 0,0041793 & 0,0041508 \\
\hline Normal Stress (MPa) & 896,15 & 895,21 & 896,41 \\
\hline
\end{tabular}

Dari tabel hasil pengujian statik diatas dapat dilihat bahwa total deformation dan normal stress pada putaran $3000 \mathrm{rpm}$ yang paling tinggi pada arah aksial dengan nilai masingmasing 12,509 $\mathrm{mm}$ dan 323,27 MPa. Sedangkan total deformation dan normal stress pada putaran $3000 \mathrm{rpm}$ yang paling rendah pada arah vertikal dengan nilai masing-masing 12,308 $\mathrm{mm}$ dan 322,07 MPa. Normal elastic strain pada putaran $3000 \mathrm{rpm}$ yang paling tinggi pada arah vertikal dengan nilai $0,0015079 \mathrm{~mm} / \mathrm{mm}$ dan yang paling rendah pada arah aksial dengan nilai $0,0014807 \mathrm{~mm} / \mathrm{mm}$

Total deformation dan normal stress pada putaran $5000 \mathrm{rpm}$ yang paling tinggi pada arah aksial dengan nilai masing-masing 34,412 $\mathrm{mm}$ dan 896,41 MPa. Sedangkan total deformation dan normal stress pada putaran $5000 \mathrm{rpm}$ yang paling rendah pada arah vertikal dengan nilai masing-masing 34,211 mm dan 895,21 MPa. Normal elastic strain pada putaran $5000 \mathrm{rpm}$ yang paling tinggi pada arah vertikal dengan nilai $0,0041793 \mathrm{~mm} / \mathrm{mm}$ dan yang paling rendah pada arah aksial dengan nilai $0,0041508 \mathrm{~mm} / \mathrm{mm}$.

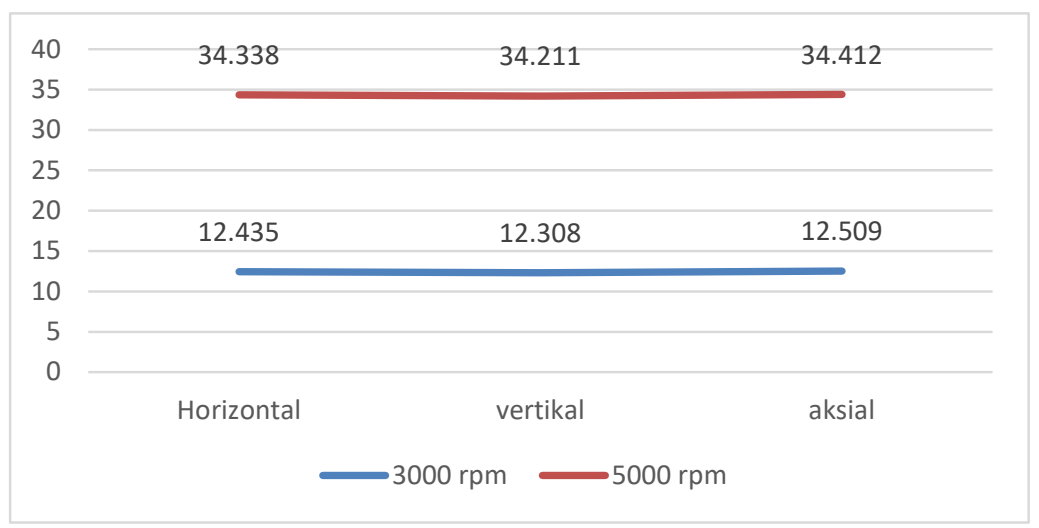

Gambar 4.3 Grafik Total Deformation

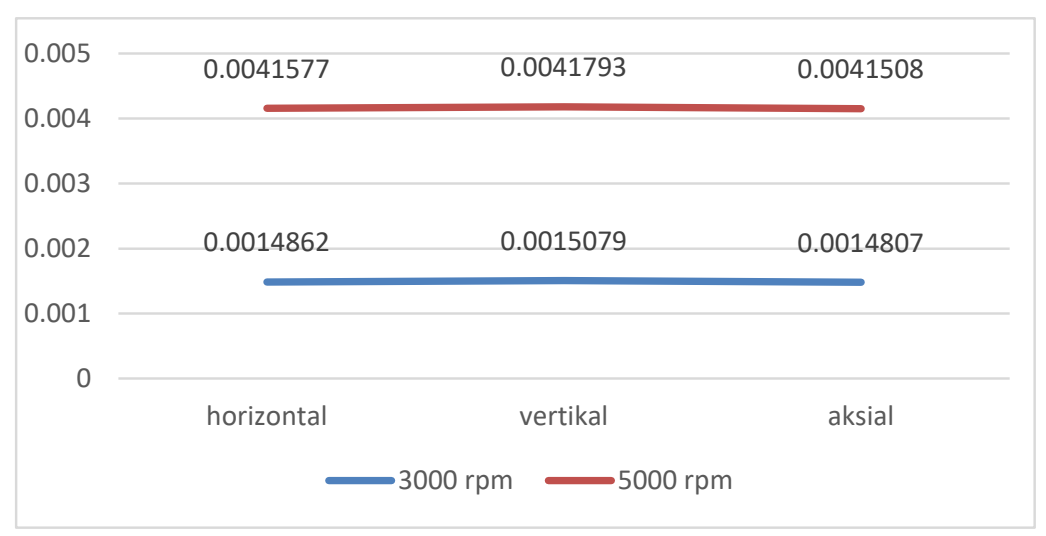


Gambar 4.4 Grafik Normal Elastic Strain

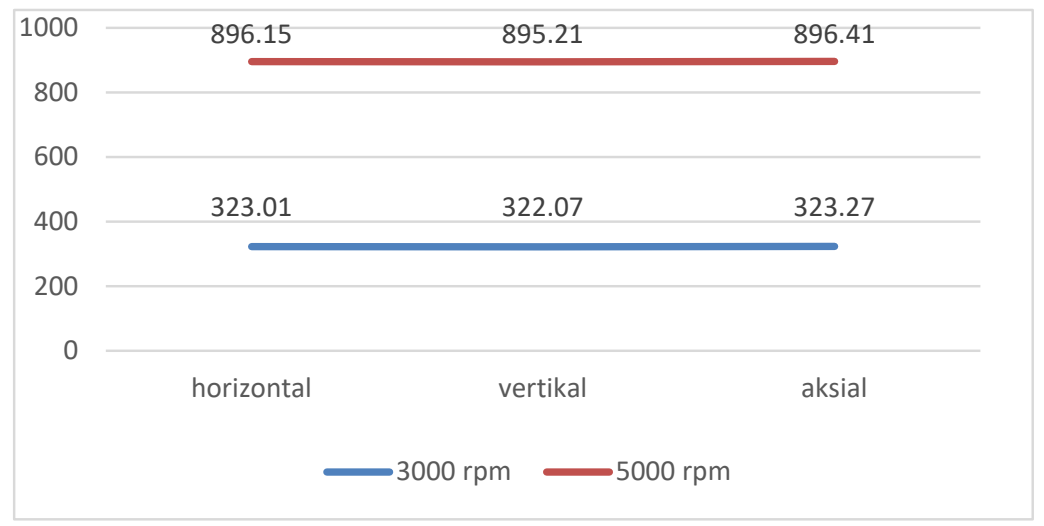

Gambar 4.5 Grafik Normal Stress

\section{KESIMPULAN}

Dari hasil perbandingan diperoleh kesimpulan bahwa total deformation dan normal mengalami kenaikan paling tinggi pada arah vertikal. Hal ini dipengaruhi oleh gaya gravitasi yang terjadi pada kompresor, karena pada arah vertikal pembebanan dilakukan berlawanan dengan gaya gravitasi. Dapat disimpulkan juga ketika kecepataan putar dirubah dari $3000 \mathrm{rpm}$ menjadi $5000 \mathrm{rpm}$, total deformation, normal elastic strain, dan normal stress hampir naik tiga kali lipat.stress mengalami penurunan pada arah vertikal sedangkan normal elastic strain dan kompresor aman dari frekuensi kritis.

\section{REFERENSI}

[1] Sularso dan Haruo Tahara. 2000. Pompa dan Kompresor. Jakarta: PT. Pradnya Paramita

[2] Karyasa, Tungga B. 2011. Dasar-Dasar Getaran Mekanis. Yogyakarta: CV. Andi Offset

[3] Sarwanto. 2012. Belajar Cepat Desain 3D dengan Solidworks. Yogyakata: PT. Media Setara

[4] Hutahen, Ramses Y. 2012. Getaran Mekanik. Yogyakarta: Andi Publiser

[5] Ryan Tua "Analisa Karakterisitik Aerodinamika Pengaruh Sirip Terhadap Airfoil Sayap Pesawat UAV USU Menggunakan Metode Computational Fluid Dynamic SOLIDWORKS”. Departemen Teknik Mesin. Fakultas Teknik. Universitas Sumatera Utara.

[6] Yendra, Andika Noveri “Analisa Aliran Fluida Proses Exhausting pada Knalpot Komposit Hybrida Batang Kelapa Sawit Melalui Metode Computational Fluid Dynamic”. Departemen Teknik Mesin. Fakultas Teknik. Universitas Sumatera Utara. 
[7] Rahmad Hidayat “Simulasi Deformasi dan Tegangan Sayap Pesawat Tanpa Awak Berbahan Komposit Serat Rock Wool dan Polyester dengan Software Ansys 14.0”. Departemen Teknik Mesin. Fakultas Teknik. Universitas Sumatera Utara.

[8] Simanjuntak, Jules Rimson "Simulasi Perilaku Mekanis Kekuatan Tarik Material Paduan Aluminium Magnesium Foam Dengan Menggunakan Software Ansys 14.0”. Departemen Teknik Mesin. Fakultas Teknik. Universitas Sumatera Utara. 